(1)
Volume 6, Nomor 1, Tahun 2020
Tersedia Online: http://ojs.uniska.ac.id/index.php/BKA
e-ISSN 2477-6300

\title{
PENGEMBANGAN MODEL LAYANAN INFORMASI TENTANG BAHAYA SEKS BEBAS PADA SISWA SMA WALISONGO PONTIANAK
}

\author{
Novi Andriati, Riki Maulana \\ Program Studi Bimbingan dan Konseling, Fakultas Ilmu Pendidikan dan Pengetahuan Sosial, IKIP-PGRI \\ Pontianak, Jalan Ampera No. 88 \\ novieandriaty@yahoo.co.id
}

\begin{abstract}
ABSTRAK
Tujuan penelitian yaitu menghasilkan model layanan informasi tentang bahaya seks bebas pada siswa SMA Walisongo Pontianak. Penelitian ini menggunakan metode Research and Development $(R \& D)$. Dari hasil uji coba lapangan pemahaman bahaya seks bebas siswa SMA mengalami perkembangan setelah mengikuti kegiatan layanan informasi. Keseluruhan nilai asymp sig 0,028<0,05 maka Ho ditolak dan Ha diterima, sehingga dapat disimpulkan bahwa layanan informasi efektif untuk meningkatkan pemahaman bahaya seks bebas siswa. Saran: penggunaan model layanan informasi sebaiknya dapat dimulai dengan mendiagnosa secara cermat kondisi objektif siswa yang akan dijadikan sebagai anggota kegiatan, sekolah diharapkan dapat memanfaatkan program bimbingan konseling, terutama layanan informasi sebagai rujukan dalam mengembangkan kebijakan bagi siswa khususnya dalam bidang pribadi dan sosial siswa di SMA Walisongo Pontianak. Oleh sebab itu, sekolah perlu menyiapkan sarana prasarana yang dibutuhkan untuk media yang digunakan dalam memberikan layanan informasi.
\end{abstract}

Kata Kunci: Layanan Informasi; Pemahaman Bahaya Seks; Remaja

\begin{abstract}
The purpose of the research is to produce a model of information service about the danger of free sex in Walisongo high school students Pontianak. This research uses the Research and Development $(R \& D)$ method. From field trials to understand the dangers of free sex, high school students develop after following information service activities. Overall value of Asymp sig $0.028<0.05$ then Ho rejected and Ha accepted, so it can be concluded that the information service is effective to increase the understanding of free sex danger students. Suggestion: The use of the information service model should be initiated by careful diagnosis of the objective conditions of the students who will be used as a member of the activities, the school is expected to utilize counseling programs, especially information services as a reference in developing the policy for students especially in the personal and social field of students in high school Walisongo Pontianak. Therefore, the school needs to prepare the infrastructure needed for the media used in providing information services.
\end{abstract}

Keywords: Information services, Comprehension of Sex RIsk, Teenagers 


\section{PENDAHULUAN}

Seks bebas merupakan sebuah tindakan melakukan hubungan seks dengan sengaja atau tidak tanpa melakukan ikatan pernikahan dengan mengabaikan norma atau etika yang berlaku di masyarakat. Tanpa seks manusia tidak akan berkembang dan kelangsungan generasi kini tidak akan terwujud, hal tersebut bermakna bahwa seks juga meliputi golongan pelajar atau remaja. Menurut Ali \& Asrori (2010: 9) menyatakan "masa remaja berlangsung antara usia 12 tahun sampai 21 tahun bagi wanita dan sampai dengan 22 tahun bagi pria, proses pertumbuhan dan perkembangannya menuju kejenjang kedewasaan". Siswa remaja adalah usia yang rentan akan tindakan-tindakan negatif, apalagi mengenai seks hal tersebut diakibatkan oleh minat keingintahuan yang tinggi dan kebutuhan psikologisnya sudah mulai berkembang. Ali (2016: 142) menyatakan bahwa "Karena minat pada seks yang semakin meningkat, remaja selalu berusaha mencari informasi yang lebih banyak tentang seks". Jelaslah bahwa siswa sudah memulai motivasi dirinya terhadap seks dan jika hal tersebut diketahui tanpa bimbingan atau pengarahan yang baik maka akan berakibat fatal. Secara umum faktor yang melatarbelakangi seks bebas adalah faktor internal dan faktor eksternal. Faktor internal yaitu faktor yang berasal dari dalam diri siswa itu sendiri yang mengalami perubahan biologis dan sosiologis. Sedangkan faktor eksternal yaitu faktor yang berasal dari luar diri siswa itu sendiri (keluarga, pergaulan dengan teman sebaya, dan lingkungan). Saat ini untuk menekankan jumlah perilaku seks bebas, terutama dikalangan siswa bukan hanya membentengi diri dengan unsur agama yang kuat, tetapi juga dibentengi diri dengan pendamping orang tua dan selektifitas dalam berteman. Karena ada kecenderungan siswa lebih terbuka kepada teman terdekatnya ketimbang dengan orang tuanya sendiri. Dengan berbagai masalah itu dikalangan siswa perlu segera diberikan suatu bekal pendidikan kesehatan reproduksi di sekolah-sekolah, namun bukan pendidikan seks secara vulgar.

Pendidikan kesehatan reproduksi di kalangan siswa bukan hanya memberikan pengetahuan tentang organ reproduksi, tetapi bahaya seks bebas, seperti penyakit menular seksual dan lainnya. Dengan demikian, para siswa bisa terhindar dari percobaan melakukan seks bebas. Penelitian oleh Ghea (2013: 45) menyatakan bahwa disalah satu SMP di Mojokerto dijumpai siswa menyimpan video porno dan gambar-gambar yang tidak selayaknya untuk usianya saat razia handphone. Tindakan yang dilakukan terhadap siswa yang menyimpan video porno itu mendapatkan sanksi dari sekolah yaitu langsung di keluarkan dari sekolah.Siswa biasanya melakukan segala sesuatu tanpa berfikir sehingga dapat membawa dampak buruk bagi dirinya maupun keluarganya, Dikhawtirkan siswanya terjerat dalam pergaulan yang tidak bertanggung jawab yang akan merusak masa depannya kelak.

Bimbingan dan Konseling merupakan bagian dari pendidikan yang membantu tercapainya tujuan pendidikan. Bidang bimbingan meliputi 4 bidang yaitu bimbingan pribadi, sosial, karier dan belajar (Winkel \& Hastuti, 2008: 113). Dalam membantu dan memfasilitasi pencapaian tujuan dalam hal ini adalah bidang bimbingan pribadi dan sosial yaitu dengan membantu siswa dalam konteks bersifat pencegahan tentang bahaya seks bebas. Peran guru BK dalam memberikan pemahaman tentang bahaya seks bebas bagi siswa sangat penting, guru BK merupakan pembimbing sekaligus berperan sebagai konselor siswa dan mencegah hal-hal yang dapat menghambat perkembangan siswa. Pelaksanaan BK di sekolah yang berperan adalah guru BK, salah satu layanan yang akan digunakan yaitu layanan informasi yang terus menerus dan berkesinambungan. Menurut Nursalim (2012: 22) menyatakan bahwa layanan informasi adalah kegiatan bimbingan yang bermaksud membantu siswa untuk mengenal diri dan lingkungannya.

Peneliti memperoleh informasi dari guru BK bahwa layanan informasi tentang seks bebas belum terlaksana dengan baik, hal ini dapat dilihat dari alokasi waktu dalam pemberian layanan yang disediakan kurang, Sehingga saat menyampaikan materi hanya bersifat umum kepada siswa. Guru BK khawatir siswa tidak bisa memperoleh informasi yang akurat tentang bahaya seks bebas, seperti penyakit yang dapat ditularkan dari hubungan seks bebas serta terjerumus dalam pergaulan yang tidak bertanggung jawab dapat merusak masa depannya kelak. Oleh karena itu, meskipun waktu yang disediakan kurang memadai guru BK secara khusus di SMA Walisongo Pontianak berusaha untuk membantu memberikan pemahaman kepada siswa tentang bahaya seks bebas. Salah satu layanan bimbingan dan konseling yang akan dilaksanakan menggunakan layanan informasi. Tujuan layanan informasi adalah untuk membekali individu dengan berbagai pengetahuan dan pemahaman tentang bahaya seks bebas yang berguna untuk mengenal diri, merencanakan dan mengembangkan pola kehidupan sebagai pelajar, anggota keluarga dan masyarakat. Menurut Prayitno (2012: 50) menjelaskan fungsi yang ingin dicapai dari layanan informasi di sekolah adalah memberi bantuan kepada siswa dalam menyusun 
Novi Andriati, Riki Maulana

Jurnal Bimbingan dan Konseling Ar-Rahman

Volume 6, Nomor 1, Tahun 2020

e-ISSN 2477-6300

rencana pendidikannya secara cermat dan tepat serta dapat dipertanggung jawabkan. Layanan informasi tentang pendidikan seks tidak hanya dilakukan di sekolah menengah pertama akan tetapi pendidikan seks dan bahaya seks bebas diberikan untuk semua sekolah dari sekolah dasar sampai jenjang pendidikan tinggi dan tidak terkecuali Sekolah Menengah Atas Walisongo. Diharapkan dengan adanya layanan informasi tentang bahaya seks bebas siswa dapat menjauhi seks bebas yang dewasa ini banyak melibatkan remaja.

Aydin (2009) mengatakan bahwa penelitian ini terbukti bahwa bimbingan konseling dapat meningkatkan pemahaman remaja tentang seks yaitu membantu meningkatkan motivasi siswa dalam pemahaman diri terhadap perkembangan seks pada tahun pertama sekolah, secara tidak langsung penelitian ini mempunyai tujuan yang sama yaitu selalu meningkatkan pemahaman siswa tentang bahaya seks. Penelitian (Driessens, 2004) menyatakan bahwa penelitian ini dilaksanakan dalam menganalisis kemampuan siswa belajar melalui bimbingan klasikal. Bimbingan yang diberikan diharapkan siswa bisa memahami tentang pentingnya pengulangan kembali materi yang diberikan oleh guru untuk dilaksanakan dalam proses pemahaman seks. Melalui penelitian ini, bimbingan klasikal efektif sebagai analisa kemampuan siswa dalam belajar.

Penelitian Helen \& Kuruvilla (2011) menyebutkan bahwa masa remaja adalah masa transisi dimana adanya perubahan dari masa anakanak menuju masa dewasa, pada masa ini banyak gejolak atau perubahan-perubahan yang dialami oleh remaja. Pada masa ini tidak sedikit remaja putri yang berperilaku negatif karena pengaruh lingkungan seperti putus sekolah dan melakukan free sex sehingga banyak gadis yang hamil. Rendahnya kepercayaan diri pada remaja mengakibatkan mudahnya remaja terbawa pengaruh negatif karena tidak yakin akan dirinya. Melalui penelitian eksperimen ini terbukti bahwa konseling kelompok efektif meningkatkan kepercayaan diri pada remaja putri.

\section{METODE}

Penelitian ini menggunakan jenis penelitian pengembangan atau Research and Development (R\&D), yaitu jenis penelitian yang digunakan untuk menghasilkan produk tertentu, dan menguji keefektifan produk tersebut (Borg \& Gall, 2007: 271). Dasar pertimbangan penggunaan pendekatan ini adalah didasarkan pada prinsip-prinsip dan langkah-langkah sesuai strategi penelitian dan pengembangan efektif untuk mengembangkan dan validasi produk pendidikan (Sugiyono, 2010: 407). Produk pendidikan yang dapat dihasilkan melalui pendekatan penelitian dan pengembangan adalah buku teks, film instruksional, program komputer, metode mengajar, dan berbagai program pendidikan lainnya. Tujuan dari penelitian ini tersusunnya suatu pengembangan model layanan informasi untuk meningkatkan pemahaman tentang bahaya seks bebas. Kerangka isi dan komponen model dirancang berdasarkan kajian konsep bimbingan dan konseling, kajian konsep seks bebas, serta kajian empiris tentang kondisi faktual layanan informasi di SMA Kota Pontianak, khususnya bimbingan dan konseling di SMA Walisongo Pontianak. Penelitian pengembangan diarahkan sebagai proses pengembangan dan validasi produk. Produk yang dimaksud adalah sebuah model layanan informasi untuk meningkatkan pemahaman bahaya seks bebas siswa kelas $\mathrm{X}$ di SMA Walisongo Pontianak. Berdasarkan tahapan yang akan dilaksanakan maka secara keseluruhan rancangan yang digunakan dalam penelitian ini adalah rancangan penelitian dan pengembangan (research and development).

Langkah-langkah yang ditempuh dalam penelitian ini meliputi: (1) studi pendahuluan, (2) perencanaan, (3) pengembangan model hipotetik, (4) penelaahan model hipotetik, (5) revisi, (6) uji coba terbatas. Jenis instrumen pengumpulan data yang digunakan dalam penelitian ini adalah Pedoman wawancara dan pedoman observasi. Instrumen terdiri dari dari 54 item pernyataan yang digunakan untuk mengukur tingkat pemahaman tentang bahaya seks siswa kelas $\mathrm{X}$ di SMA Walisongo. Penelitian ini menggunakan dua metode penelitian yaitu kualitatif dan kuantitatif secara terpadu, maka teknik analisa data pun dilakukan secara terpadu. Analisis data dalam penelitian ini diarahkan dalam tiga tahap: tahap pertama, analisis data penelitian pada tahapan ini dilakukan secara kuantitatif dan kualitatif. Prosedur kuantitatif dilakukan dengan menghitung persentase pemahaman bahaya seks bebas siswa. Prosedur kualitatif dilakukan untuk memaknai deskripsi kondisi faktual tentang pelaksanaan layanan informasi di sekolah. Hasil analisis ini dijadikan dasar untuk menyusun model awal. Tahap kedua menggunakan prosedur kualitatif. Bentuk analisisnya adalah uji kelayakan model dengan mempertimbangkan masukan dari validator ahli dan praktisi. Hasil dari analisis ini digunakan untuk melakukan perbaikan dari model awal. Tahap ketiga, dianalisis dengan prosedur kualitatif dan kuantitatif. Bentuk analisis kualitatif yang dilakukan adalah menelaah proses implementasi model yang dikembangkan. Sedangkan analisis kuantitatif dilakukan dengan menghitung persentase pemahaman tentang bahaya seks bebas siswa setelah dikenai model layanan informasi. 
Hasil dari analisis ini digunakan sebagai dasar untuk menyusun model akhir layanan informasi untuk meningkatkan pemahaman bahaya seks bebas siswa.

\section{HASIL DAN PEMBAHASAN}

Gambaran tentang pemahaman siswa tentang bahaya seks bebas secara khusus di kelas X SMA Walisongo diperoleh dari hasil penyebaran skala pemahaman siswa tentang bahaya seks yang berjumlah 120 siswa yang terbagi menjadi 6 kelas. Kemudian peneliti memberikan instrumen berupa skala pemahaman tentang bahaya seks kepada 90 siswa pada kelas A, B, C, D, E, F. Semua siswa mengerjakannya sesuai dengan petunjuk yang dijelaskan oleh peneliti. Perolehan skor gambaran pemahaman tentang bahaya seks bebas siswa berdasarkan indikator terlihat dalam tabel 2 .

Dari tabel 2, terlihat bahwa jumlah siswa yang memiliki pemahaman bahaya seks rendah adalah 25 siswa (19.4\%) dan siswa yang memiliki pemahaman bahaya seks tinggi terdapat 65 siswa (80.6\%). Untuk mempermudah melihat, peneliti menyajikan dalam bentuk grafik pada gambar 1 .

Tabel 1. Kategori Tolak Ukur

\begin{tabular}{rcl}
\hline Interval & Persentase & \multicolumn{1}{c}{ Kategori } \\
\hline $176-216$ & $75.01 \%-100 \%$ & Sangat Tinggi \\
$135-175$ & $50.01 \%-75 \%$ & Tinggi \\
$94-134$ & $25.01 \%-50 \%$ & Rendah \\
$54-93$ & $0-25 \%$ & Sangat Rendah \\
\hline
\end{tabular}

Tabel 2 Sebaran Pemahaman Tentang Bahaya Seks Bebas Siswa Berdasarkan Indikator

\begin{tabular}{|c|c|c|c|c|c|c|c|}
\hline \multirow{2}{*}{ No. } & \multirow{2}{*}{ Indikator } & \multirow{2}{*}{ F } & \multicolumn{4}{|c|}{ Kategori } & \multirow{2}{*}{$\Sigma$} \\
\hline & & & ST & $\mathbf{T}$ & $\mathbf{R}$ & SR & \\
\hline \multirow[t]{2}{*}{1} & Bahaya seks bebas secara biologis & $\mathrm{F}$ & & 122 & 53 & - & 175 \\
\hline & & $\%$ & & 70 & 30 & - & $100 \%$ \\
\hline \multirow[t]{2}{*}{2} & Bahaya seks bebas secara & $\mathrm{F}$ & - & 132 & 43 & - & 175 \\
\hline & psikologis & $\%$ & - & 75 & 25 & - & $100 \%$ \\
\hline \multirow[t]{2}{*}{3} & Bahaya seks bebas secara moral & $\mathrm{F}$ & - & 116 & 59 & - & 175 \\
\hline & dan etika & $\%$ & - & 66.3 & 33,7 & - & $100 \%$ \\
\hline \multirow[t]{4}{*}{4} & Bahaya seks bebas dalam & $\mathrm{F}$ & - & 124 & 51 & - & 175 \\
\hline & lingkungan sosial & $\%$ & - & 70.8 & 29.2 & - & $100 \%$ \\
\hline & Pata Pata & $\mathrm{F}$ & & 424 & 236 & 40 & 700 \\
\hline & Kata-Kata & $\%$ & & 60.57 & 33.71 & 5.71 & $100 \%$ \\
\hline
\end{tabular}

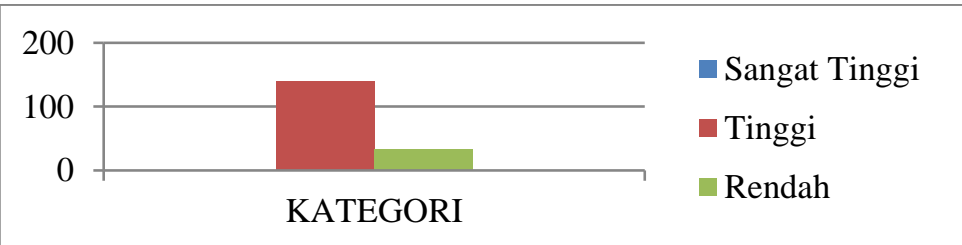

Gambar 1. Tingkat Pemahaman Tentang Bahaya Seks Bebas Siswa SMA Walisongo

Karakterisitk yang diungkap melalui skala pemahaman bahaya seks bebas terdiri dari empat aspek yaitu; (1) bahaya seks bebas secara biologis, (2) bahaya seks bebas secara psikologis, (3) bahaya seks bebas secara moral dan etika, (4) dan bahaya seks bebas dalam lingkungan sosial. Observasi dilakukan dengan menyediakan lembar observasi berjumlah 25 item deskriptor penilaian. Peneliti menyusun model layanan informasi tentang bahaya seks bebas yang akan dikembangkan terdiri dari 6 komponen utama, sebagaimana terlihat pada gambar 2.
Uji kelayakan model, peneliti melaksanakan uji 4 orang ahli dan uji 7 orang praktisi. Uji ahli dilakukan oleh pakar bimbingan dan konseling, sedangkan uji praktisi dilakukan oleh guru BK/konselor disekolah. Secara kuantitatif meningkatnya pemahaman tentang bahaya seks siswa bisa dilihat dari perbandingan nilai evaluasi awal dan evaluasi akhir yang diperoleh dari 40 siswa yang diberikan layanan informasi terjadi peningkatan skor pemahaman tentang bahaya seks bebas. Skor rata-rata pemahaman tentang seks bebas dapat dilihat pada tabel 3 .

Dipublikasikan Oleh :

UPT Publikasi dan Pengelolaan Jurnal

Universitas Islam Kalimantan Muhammad Arsyad Al-Banjari Banjarmasin 
Novi Andriati, Riki Maulana

Jurnal Bimbingan dan Konseling Ar-Rahman

Volume 6, Nomor 1, Tahun 2020

e-ISSN 2477-6300

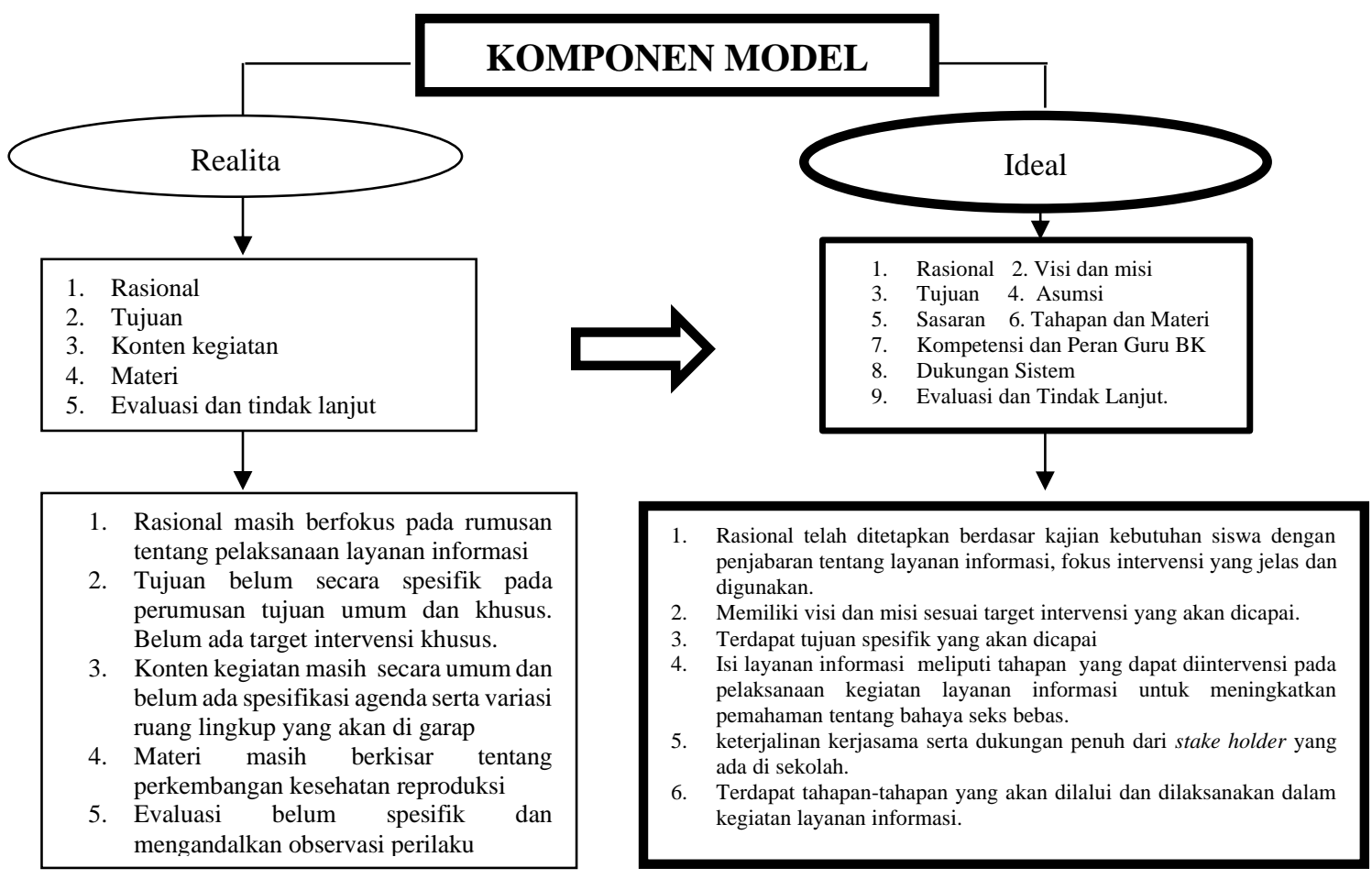

Gambar 2. Model Hipotetik Layanan Informasi Tentang Bahaya Seks Bebas

Tabel 3. Data Skor Rata-rata Pemahaman Tentang Bahaya Seks Bebas Siswa

\begin{tabular}{lccc}
\hline Keterangan & Pre Tes & Post Test & Peningkatan \\
\hline Pemahaman Tentang Bahaya Seks & 963 & 1.084 & 121 \\
\hline
\end{tabular}

Berdasarkan tabel 3 dapat dilihat bahwa skor rata-rata pada pemahaman bahaya seks siswa pada saat pre test adalah 963 dan skor rata-rata pada posttest pemahaman tentang bahaya seks siswa adalah 1.084 mengalami peningkatan 121 poin. Hasil uji $\mathrm{t}$ tes diperoleh thitunga 14.622 sementara $\mathrm{t}$ tabel dengan df $\mathrm{N}-1=46-1=45$ dengan taraf signifikasi 5\% sebesar 1.67943. oleh karena t hitung $>$ t tabel yakni 14.622>1.67943. berdasarkan hasil data tersebut dapat ditarik kesimpulan bahwa penerapan layanan informasi dapat meningkatkan pemahaman tentang bahaya seks bebas siswa.

Hasil penelitian menunjukan bahwa rata-rata tingkat pemahaman siswa tentang bahaya seks bebas setelah mengikuti kegiatan layanan informasi mengalami peningkatan, dengan demikian dapat disimpulkan bahwa pemahaman siswa tentang bahaya seks bebas siswa sebelum mendapatkan layanan informasi dengan sesudahnya adalah berbeda dan mengalami peningkatan yang signifikan. Layanan informasi efektif dalam meningkatkan pemahaman tentang bahaya seks bebas, siswa menjadi lebih paham tentang bahaya yang terjadi, yaitu bahaya secara biologis, psikologis, moral dan etikas, serta secara lingkungan sosial. Adanya pengetahuan yang didapatkan dalam pemberian layanan informasi sehingga berpengaruh terhadap sikap siswa yang menuju kearah positif. Hal ini sejalan dengan pendapat (Ahmad, J. 2012: 19) yang menyatakan tujuan layanan informasi adalah agar individu memiliki pengetahuan yang memadai, baik tentang dirinya maupun tentang lingkungannya, serta sumber-sumber belajar termasuk internet.

Layanan Informasi adalah bertujuan agar siswa mengetahui dan menguasai informasi yang selanjutnya dimanfaatkan untuk keperluan hidupnya sehari-hari dan perkembangan dirinya.Sejalan dengan ini menurut Hibana, S. (2007: 47) menyatakan tujuan layanan informasi sebagai berikut: 1) Agar siswa memiliki pengetahuan tentang lingkungan yang diperlukan untuk memecahkan masalah yang dihadapi berkaitan dengan lingkungan sekitarnya, pendidikan, jabatan, maupun sosial budaya, 2) Memungkinkan siswa untuk menentukan arah hidupnya, menentukan segala yang harus dilakukan serta cara bertindak secara kreatif dan dinamis berdasarkan informasi yang ada, 3) Setiap individu memiliki keunikan yang akan membawanya kepada 
kekhasan dalam mengambil keputusan dan bertindak yang berbeda sesuai dengan aspek kepribadian masing-masing.

\section{PENUTUP}

Gambaran umum pemahaman tentang bahaya seks bebas pada siswa SMA Walisongo tergolong rendah. Hal ini dapat dinterpretasikan melalui 4 aspek bahaya seks bebas yaitu: bahaya seks bebas secara biologis, bahaya seks bebas secara psikologis, bahaya seks bebas secara moral dan etika, bahaya seks bebas dalam lingkungan sosial. Model layanan informasi tentang bahaya seks bebas terdiri dari 1) Rasional, 2) Visi dan Misi, 3) Tujuan, 4) Asumsi, 5) Sasaran, 6) Tahapan dan Materi, 7) Kompetensi dan Peran Guru BK, 8) Dukungan System, 9) Evaluasi dan Tindak Laniut. Model layanan informasi terbukti efektif untuk meningkatkan pemahaman tentang bahaya seks bebas siswa. Simpulan ini didasarkan pada hasil perbandingan antara sebelum dan sesudah mengikuti kegiatan layanan informasi. Saran: Penelitian selanjutnya memperluas subjek penelitian, sehingga tidak hanya pada jenjang SMA, akan tetapi di SMP dan perguruan tinggi atau bentuk kelompok lain sehingga keefektifan model dapat digeneralisasikan secara lebih luas.

\section{REFERENSI}

Ali, M. (2001). Pendidikan Seks bagi remaja. Yogyakarta: Mitra pustaka.

Ali \& Asrori. (2004). Perkembangan peserta didik. Malang: Wineka Media.

Aydin, D. (2009). Efectiveness Of A Group Guidance Program On Realistic Study Field Choice Among First Year High School Students. Jurnal of Education, Volume 5 No. 1. Hal 67-84.

Borg \& Gall. (2007). Educational Research. USA: Pearson.

Driessens. (2004). Integrating Guidance into Relational Reinforcement Learning. Jurnal of Education, 34(57), 271-304.

Hellen \& Kuruvilla. (2011). Effectiveness Of Group Counseling On The Level Of Self-Esteem Of Adolescent School Girls. Jurnal of Education, 2(3), 28-32.

Ghea. (2013). Penerapan Bimbingan Kelompok Teknik Home Room Untuk Meningkatkan Pemahaman Siswa Tentang Bahaya Seks Bebas. Jurnal Mahasiswa Bimbingan Konseling, 1(1), 79-93.

Hibana, S. (2007). Bimbingan dan Konseling Pola 17. Yogyakarta: UCY Press.
Nurihsan, A.J. (2012). Bimbingan dan Konseling dalam Berbagai Latar Kehidupan. Bandung: Rafika Aditama.

Nursalim. (2012). Layanan Bimbingan dan Konseling. Surabaya : Unesa University Press.

Prayitno. (2012). Pedoman Pengawasan Bimbingan dan Konseling. Jakarta: PT Remaja Rosdakarya.

Sugiyono. (2010). Metode Penelitian Pendidikan. Bandung: Alfabeta.

Winkel \& Hastuti. (2008). Bimbingan dan Konseling di Institusi Pendidikan. Yogjakarta: Media Abadi. 